\title{
ASSESSMENT OF CULTIVARS X ENVIRONMENT INTERACTIONS FOR YIELD AND SOME OF ITS COMPONENTS IN SOME COTTON VARETIES
}

\author{
R. A. El-Refaey(1), M. M. Awaad(2), A. A. El-Gammal(1) \\ and M. F. H. Mohamed(2) \\ (1) Faculty of Agriculture, Tanta University \\ (2) Cotton Research Institute, Agricultural Research Center.
}

Received: Nov. 21, 2018

Accepted: Nov. 29,2018

\begin{abstract}
The eight cultivars included in this study were two long stable cultivars; Giza 86 and Giza 94 and six extra-long staple; Giza45, Giza 87, Giza 88, Giza 92, Giza 93 and Giza 96. These cultivars were grown at seven locations over the two seasons of 2014 and 2015. These locations were: Kafr El-Sheikh, El-Gharbia, Domietta, El-Sharkeia, ElBeheira, El-Dakahlia and El-Menufia governorates. Analysis of variance for randomized complete block design was done for each location. Then combined analyses of variance were calculated for 8 cultivars, seven locations over two seasons. Differences between means were compared by using the least significant differences (L.S.D.) was done.
\end{abstract}

The mean squares of seasons were insignificant for all yield components traits, except for lint percentage and seed index. Mean squares of locations and cultivars, had highly significant effects on all yield and its components, except for lint index. Seasons $x$ locations and cultivars $\times$ locations interaction mean squares had highly significant effects on yield and its components, except for lint index. Meanwhile, Cultivars $\times$ seasons interaction and the second order interaction cultivar $x$ season $x$ location interaction mean squares had significant effects on seed cotton and lint cotton yields, lint percentage and seed index.

The obtained results pointed out that, Giza 86 cultivar had the highest values for seed cotton and lint cotton yields, boll weight and seed and lint index, followed by Giza 87 cultivar. While, Giza 45 cultivar gave the lowest values for yield and all studied of yield components.

The performance of traits studied significantly varied according to cultivars, seasons, locations and their interactions.

Key words: Cultivars, mean squares, environments, locations and cotton.

\section{INTRODUCTION}

The Egyptian cotton is a unique type of cotton that is characterized by high quality, from the commercial production side, it is "The High Quality Cotton" that has been developed in Egypt.

Cotton (Gossypium barbadense L.) is an important crop in Egypt as well as allover the world. Cotton crop is mainly cultivated for fiber and oil. It provided row material for the Egyptian textile industry. In Egypt, cotton is important for both export and local textile industry. The total cultivated area decreased from two million to 336 thousand feddan in the growing season of 2018. While, domestic productivity is about 1.8 thousand kentars during the season of 2017. Cotton area of cultivation extends longitudinally about $700 \mathrm{Km}$ from North to South Egypt. Because environmental conditions vary or likely to vary from one location to another and/or from season to season, in this extended area, the magnitude of the cultivar by environmental interaction has become essential in helping plant breeder 
to reach many of the decisions concerning his breeding programs. The evaluation process of the commercial cultivars as well as the newly released or promising strains over different locations and over different seasons is great importance to the breeder.

Cultivars-environment interaction has a major importance for plant breeders because it testing under different environments affects the relative ranking of tested cultivars, where they differ in their ranking. That is, the phenotypic response to change of environments is not the same for all cultivars.

The differential response of a cultivar or cultivars for a given traits across environments is defined as cultivar $x$ environment interaction ( $\mathrm{G} \times \mathrm{E}$ ).

The magnitude of the cultivars by environment has become essential in helping plant breeder to reach many of the decisions concerning his breeding programs. This differential response by cultivars when subjected to different environments is not the same for all cultivars. This inter-play of the genetic determinants and non-genetic ones on development is referred to as cultivar by environment interaction.

Several workers studied the performance of cotton cultivars under different environments; in this concern, Mohamed et al. (2003), El-Adly and Eissa (2010), Ali et al. (2012) and Orabi (2013) where they evaluated some cultivars in different locations and seasons, They stated that the studied cultivars differed in their yield and its components from one location and growing season to another. Furthermore, Badr, and El-Sayed (2004), Hassan et al. (2005), Shaker et al., (2013) and Abd El-Samee (2015) illustrated that, the effects of cultivars, locations, seasons and their interactions on yield and yield components were significant in most cases.
The main objective of the present study was to assessment the effect of cultivars, locations, seasons and their interactions on some yield and yield components in some Egyptian cotton varieties.

\section{MATERIALS AND METHODS}

The materials of this study included two long staple cultivars; Giza 86 and Giza 94, in addition to, six extra-long staple cultivars; Giza 45, Giza 87, Giza 88, Giza 92, Giza 93 and Giza 96. These cultivars were grown at seven locations; Kafr ElSheikh, El-Gharbia, Domietta, El-Sharkeia, El-Beheira, El-Dakahlia and El-Menufia governorates, over the two seasons of 2014 and 2015. The experimental design was a randomized complete block design with four replications at each location. The plot size was $13 \mathrm{~m}^{2}$ and each plot contained five ridges of four meters long and $65 \mathrm{~cm}$ wide. Sowing was done in hills of $25 \mathrm{~cm}$ intra - spacing. Afterwards, hills were thinned to two healthy seedlings per hill after six weeks of sowing. Before sowing, experimental plots were dressed with calcium super-phosphate (15.5\% $\mathrm{P}_{2} \mathrm{O}_{5}$ ) at the rate of $24 \mathrm{~kg} \mathrm{P}_{2} \mathrm{O}_{5} /$ faddan during the preparation of experimental fields. Plants were fertilized with nitrogen in form of ammonium nitrate $(33.5 \% \mathrm{~N})$ at the rate of $60 \mathrm{~kg} /$ faddan given into two equal doses applied before the second and third irrigations for all locations. Other cultural practices were done as recommended for cotton growing in the area, and were applied properly in the two seasons at all locations. The yield was obtained from three middle rows of each plot. The cultivars were evaluated for their yield traits; seed cotton yield (k/f), lint cotton yield (k/f), lint percentage $\%$, seed index (g) and lint index (g).

Analysis of variance (ANOVA) for randomized complete blocks design was done according to Senedecor and Cochran (1982) for each location. Then, combined analyseis of variance were calculated for 8 cultivars, seven locations 
and two seasons in the case of homogeneity variance as outlined by Bartlett, 1937. Differences between means were compared by using the least significant differences (L.S.D.). The form of the analysis of variance and the expectations of mean squares were followed after Le-Clerg et al. (1962) and Mcintosh (1983) as presented in Table (1).

Separate estimates of the components of variation in each mean squares expectation were calculated to evaluate the magnitude of the different effects. The estimates of these variance components and the expected composition of the mean squares were determined by the procedures described by Miller et al. (1959).

\section{RESULTS AND DISSCUSION}

This investigation carried to evaluate eight Egyptian cotton cultivars tested under seven different locations during the two seasons (2014 and 2015) in order to study the effects of cultivars, seasons, locations, and the interaction between them on yield and some of its components in Egyptian cotton.

\section{Analysis of variance:}

The combined analysis of variance for eight cultivars over fourteen environments (seven locations in the two seasons) is presented in Table (2).
It is clear that, the mean squares of seasons were found to be insignificant for all yield component traits, except for lint percentage and seed index, indicated that the effect of seasons could be changed from season to another for these characters, while for unexcepted traits i.e., seed cotton and lint cotton yields, boll weight and lint index, the effect of seasons did not changed from season to another due to insignificant of mean squares for these traits.

With respect to locations and cultivars, the data listed in Table (2) indicated that, its mean squares had highly significant effects for all yield and its components, except for lint index. This might indicated that, these traits could be changed from location to another and from cultivar to another, while for the excepted trait i.e., lint index, the performance of this trait did not changed with the change of locations or cultivars.

Season's $x$ locations and cultivars $x$ locations interaction mean squares had highly significant effects on yield and its components, except for lint index where the interaction effects did not reached to the level of significance. This might indicated that, seasons and cultivars more influenced by locations for traits, while it did not so far lint index.

Table (1): Expected mean squares and degree of freedom with fixed cultivars effect and random season, replicate and location effects.

\begin{tabular}{|c|c|c|c|c|}
\hline S. O. V & \multicolumn{2}{|l|}{ d.f } & \multicolumn{2}{|l|}{ Expectation of mean squares } \\
\hline Seasons (S) & $(S-1)$ & 1 & & \\
\hline Locations (L) & $(L-1)$ & 6 & & \\
\hline$S \times L$ & $(S-1)(L-1)$ & 6 & & \\
\hline Rep. in exper.(Ea) & LS $(r-1)$ & 42 & & \\
\hline Cultivars (C) & $(C-1)$ & 7 & $\sigma^{2} e+r \sigma_{G S L}^{2}+r S \sigma_{G L}^{2}+r l \sigma_{G S}^{2}+r l S \sigma_{G}^{2}$ & M5 \\
\hline $\mathrm{C} \times \mathrm{S}$ & $(C-1)(Y-1)$ & 7 & $\sigma^{2} e+r \sigma_{G S L}^{2}+r l \sigma_{G S}^{2}$ & M4 \\
\hline$C \times L$ & $(C-1)(L-1)$ & 42 & $\sigma^{2} e+r \sigma_{G S L}^{2}+r y \sigma_{G L}^{2}$ & M3 \\
\hline $\mathrm{C} \times \mathrm{S} \times \mathrm{L}$ & $(C-1)(Y-1)(L-1)$ & 42 & $\sigma^{2} e+r \sigma_{G S L}^{2}$ & M2 \\
\hline Error (b) & LC (r-1) (G-1) & 294 & $\sigma^{2} e$ & M1 \\
\hline
\end{tabular}


Table (2): Mean squares for yield and yield components for eight Egyptian cotton cultivars grown at seven locations over two seasons (2014 and 2015).

\begin{tabular}{|c|c|c|c|c|c|c|c|}
\hline S. O. v. & df & $\begin{array}{c}\text { Seed } \\
\text { cotton } \\
\text { yield }(K / F)\end{array}$ & $\begin{array}{l}\text { Lint cotton } \\
\text { yield K/F) }\end{array}$ & $\begin{array}{c}\text { Boll } \\
\text { weight }(g)\end{array}$ & $\begin{array}{c}\text { Lint } \\
\text { percentage } \\
\%\end{array}$ & $\begin{array}{c}\text { Seed } \\
\text { index }(g)\end{array}$ & $\begin{array}{l}\text { Lint index } \\
\text { (g) }\end{array}$ \\
\hline Seasons (S) & 1 & 33085.94 & 28608.04 & 0.005 & $23.8651^{\star *}$ & $0.3657^{* *}$ & 2.3868 \\
\hline Locations (L) & 6 & $21646810^{* *}$ & $2930885^{\star *}$ & $0.3855^{\star *}$ & $3.8896 * *$ & $9.6892^{\star *}$ & 4.0896 \\
\hline Cultivars (C) & 7 & $1717231^{\star *}$ & $281360.2^{\star *}$ & $1.734^{\star \star}$ & $61.2017^{* *}$ & $18.7075^{\star *}$ & 14.3112 \\
\hline$S \times L$ & 6 & $42071430^{* *}$ & $5792381^{* *}$ & $0.6439 * *$ & $6.7728^{\star *}$ & $5.8364^{* *}$ & 3.2333 \\
\hline $\mathrm{C} \times \mathrm{S}$ & 7 & $1940132^{* *}$ & $290349.4^{\star *}$ & 0.0051 & $1.4112^{\star \star}$ & $0.1715^{\star *}$ & 0.1817 \\
\hline C XI & 42 & 896654.1** & $117861.5^{\star *}$ & $0.039 * *$ & $1.7099^{* *}$ & $0.3296^{* *}$ & 0.2296 \\
\hline $\mathrm{C} \times \mathrm{S} \times \mathrm{L}$ & 42 & 645952.4** & $95878.8^{\star *}$ & 0.0124 & $1.2188^{* *}$ & $0.1065^{\star *}$ & 0.081 \\
\hline Error & 294 & 162308.5 & 23296.73 & 0.0092 & 0.2539 & 0.0443 & 0.0275 \\
\hline
\end{tabular}

*, ** Significant at 0.05 and 0.01 probability levels, respectively.

Cultivars $\times$ seasons interaction and the second order interaction; cultivar $x$ season $x$ location interaction mean squares had significant effects on seed cotton, lint yields, lint percentage and seed index, while for boll weight and lint index the same interactions did not reach to the significant level. these results indicated that, the cultivars performed in different under different locations and seasonal change.

These results are in harmony with those reviewed by Hassan (2000), Badr and Hassan (2003), Rahouma et al. (2008), Shaker (2009), and El-Ganainy, Hanan (2017).

\section{Mean performance:}

\subsection{Cultivars mean performance:}

Results listed in Table (3) showed that, cultivars recorded highly significant effect for all traits of yield and yield components. These Results indicated that there Cultivars could be attributed to there Cultivars belonging to different species of cotton which could be attributed to genetic makeup.
Regarding to seed cotton and lint cotton yields (k/f) (Table 3 ) it was observed that, Giza 86 yielded the highest seed cotton yield and lint cotton yield (9.69 and $11.33 \mathrm{k} / \mathrm{f}$.), respectively, followed in order by Giza 93, Giza 88 which gave 11.11 and $10.68 \mathrm{k} / \mathrm{f}$, respectively, and differences between them were not significant. However, the lowest seed cotton yield and lint cotton yield were (7.75 and $8.62 \mathrm{k} / \mathrm{f}$ ) respectively, produced by the commercial cultivar Giza 45. Giza 86 surpassed significantly Giza 94, Giza 87 and Giza 96 in seed cotton by $0.78,0.75$ and $1.39 \mathrm{k} / \mathrm{f}$, respectively. While, the same commercial cultivar exceeded significantly Giza 94 and Giza 96 in lint cotton yield by 1.20 and $1.12 \mathrm{k} / \mathrm{f}$, respectively. These results reached to the same conclusion by Hassan et al. (2013) who reported that, the promising strain (Giza 77 x Pima S6) "Giza 93" surpassed the commercial cultivar Giza 87 in most studied traits. The long staple promising strain (10229 x Giza 86) "Giza 94" exceeded the commercial cultivar Giza 86 in all studied traits. 
Table (3): Mean performance of cotton cultivars for cotton yield and yield components averaged over seven locations and two seasons.

\begin{tabular}{|c|c|c|c|c|c|c|}
\hline Cultivars & $\begin{array}{c}\text { Seed } \\
\text { cotton } \\
\text { yield (K/F) }\end{array}$ & $\begin{array}{c}\text { Lint } \\
\text { cotton } \\
\text { yield (K/F) }\end{array}$ & $\begin{array}{c}\text { Boll } \\
\text { weight (g) }\end{array}$ & $\begin{array}{c}\text { int } \\
\text { percentage } \\
\%\end{array}$ & $\begin{array}{c}\text { Seed } \\
\text { index (g) }\end{array}$ & $\begin{array}{c}\text { Lint index } \\
(\mathrm{g})\end{array}$ \\
\hline Giza 86 & $9.69 \mathrm{a}$ & $11.33 \mathrm{a}$ & $3.35 \mathrm{a}$ & $37.09 \mathrm{c}$ & $10.12 \mathrm{~b}$ & $5.97 \mathrm{~b}$ \\
\hline Giza 94 & $8.91 \mathrm{~b}$ & $10.13 \mathrm{~b}$ & $3.13 \mathrm{c}$ & $36.11 \mathrm{f}$ & $9.06 \mathrm{f}$ & $5.12 \mathrm{~d}$ \\
\hline Giza 45 & $7.75 \mathrm{c}$ & $8.62 \mathrm{c}$ & $2.83 \mathrm{c}$ & $35.20 \mathrm{f}$ & $8.79 \mathrm{~d}$ & $4.78 \mathrm{e}$ \\
\hline Giza 87 & $8.94 \mathrm{~b}$ & $10.54 \mathrm{~b}$ & $3.33 \mathrm{a}$ & $37.37 \mathrm{~b}$ & $10.14 \mathrm{~b}$ & $6.06 \mathrm{a}$ \\
\hline Giza 88 & $9.29 \mathrm{a}$ & $10.68 \mathrm{a}$ & $3.24 \mathrm{~b}$ & $36.47 \mathrm{e}$ & $9.73 \mathrm{c}$ & $5.59 \mathrm{c}$ \\
\hline Giza 92 & $9.27 \mathrm{a}$ & $10.65 \mathrm{~b}$ & $3.18 \mathrm{~b}$ & $36.46 \mathrm{e}$ & $9.78 \mathrm{c}$ & $5.61 \mathrm{c}$ \\
\hline Giza 93 & $9.51 \mathrm{a}$ & $11.11 \mathrm{a}$ & $3.38 \mathrm{a}$ & $36.78 \mathrm{~d}$ & $10.55 \mathrm{a}$ & $6.14 \mathrm{a}$ \\
\hline Giza 96 & $8.30 \mathrm{~b}$ & $10.21 \mathrm{~b}$ & $3.24 \mathrm{~b}$ & $38.80 \mathrm{a}$ & $9.66 \mathrm{e}$ & $6.13 \mathrm{a}$ \\
\hline L.S.D. : 0.01 & 0.726 & 0.867 & 0.047 & 0.245 & 0.103 & 0.081 \\
\hline
\end{tabular}

Concerning boll weight (g), the results in Table (3) showed that, the cultivar Giza 93 gave the highest value of boll weight (3.38 g), followed by Giza 86 (3.35 g), with insignificant differences between them. Giza 45 recorded the lowest value of boll weight $(2.83 \mathrm{~g})$. This is might illustrated why Giza 45 considered as low yielding of seed cotton and lint cotton.

With regard to lint percentage $\%$, the results shown in Table (3) demonstrated that, Giza 96 surpassed significantly all the other cultivars, it recorded (38.80\%), followed by Giza 87 and Giza 86 (37.37 and $37.09 \%$, respectively). Giza 45 gave the lowest values of lint percentage (35.20\%).

Concerning seed index (g), Giza 93 surpassed significantly the other studied cultivars (10.55 g), but the cultivar; Giza 45 gave the lowest value of seed index (8.79 g).

With respect to lint index (g.), results in Table (3), showed that, the commercial cultivar Giza 93 and Giza 96 gave the highest values, 6.14 and $6.13 \mathrm{~g}$., respectively and Giza 45 exhibited the lowest value $(4.78 \mathrm{~g})$.
However, the obtained results pointed out that, Giza 93 cultivar had the highest values for seed and lint cotton yields, boll weight and seed and lint index, followed by Giza 87 cultivar. While, Giza 45 cultivar gave the lowest values for yield and all studied of yield components. In this respect El-Ganainy, Hanan (2017) recorded that, Giza 94 surpassed all cultivars for boll weight, lint percentage, seed and lint index.

\section{2 . Locations mean performance:}

The data listed in Table (4) suggested that, the highest values of seed cotton yield and lint cotton yield were 11.51 and 11.21 k/f. for seed cotton yield and 13.49 and $12.91 \mathrm{k} / \mathrm{f}$. for lint cotton yield, for the cotton cultivars grown at Kafr El-Sheikh and El-Gharbia governorates, respectively, with no significant difference between them. While, the lowest values of seed cotton yield and lint cotton yield were 5.32 and $6.20 \mathrm{k} / \mathrm{f}$ for the cotton cultivars grown at El-Menufia governorate, respectively. 
Table (4): Mean performance of locations for cotton yield and yield components over two seasons.

\begin{tabular}{|c|c|c|c|c|c|c|c|}
\hline $\begin{array}{c}\text { Growing } \\
\text { locations }\end{array}$ & $\begin{array}{c}\text { Seed } \\
\text { cotton } \\
\text { yield } \\
\text { (K/F) }\end{array}$ & $\begin{array}{c}\text { Lint } \\
\text { cotton } \\
\text { yield } \\
\text { K/F) }\end{array}$ & $\begin{array}{c}\text { Boll } \\
\text { weight } \\
(\mathrm{g})\end{array}$ & $\begin{array}{c}\text { Lint } \\
\text { percentage } \\
\%\end{array}$ & $\begin{array}{c}\text { Seed } \\
\text { index (g) }\end{array}$ & $\begin{array}{c}\text { Lint } \\
\text { index (g) }\end{array}$ & $\begin{array}{c}\text { Seed } \\
\text { cotton } \\
\text { yield } \\
\text { (K/F) }\end{array}$ \\
\hline Kafr El-Sheikh & $11.51 \mathrm{a}$ & $13.49 \mathrm{a}$ & $3.25 \mathrm{a}$ & $37.17 \mathrm{a}$ & $10.13 \mathrm{a}$ & $6.00 \mathrm{a}$ & $11.51 \mathrm{a}$ \\
\hline El-Gharbia & $11.21 \mathrm{a}$ & $12.91 \mathrm{a}$ & $3.16 \mathrm{~b}$ & $36.33 \mathrm{c}$ & $9.65 \mathrm{c}$ & $5.52 \mathrm{c}$ & $11.21 \mathrm{a}$ \\
\hline Domietta & $8.51 \mathrm{c}$ & $9.89 \mathrm{c}$ & $3.30 \mathrm{a}$ & $36.88 \mathrm{~b}$ & $10.03 \mathrm{~b}$ & $5.88 \mathrm{~b}$ & $8.51 \mathrm{c}$ \\
\hline El-Sharkeia & $7.69 \mathrm{~d}$ & $8.93 \mathrm{~d}$ & $3.11 \mathrm{~b}$ & $36.79 \mathrm{~b}$ & $9.50 \mathrm{~b}$ & $5.54 \mathrm{c}$ & $7.69 \mathrm{~d}$ \\
\hline EL-Beheira & $8.51 \mathrm{c}$ & $9.91 \mathrm{c}$ & $3.27 \mathrm{a}$ & $36.75 \mathrm{~b}$ & $10.16 \mathrm{a}$ & $5.91 \mathrm{~b}$ & $8.51 \mathrm{c}$ \\
\hline EL-Dakahlia & $9.97 \mathrm{~b}$ & $11.53 \mathrm{~b}$ & $3.27 \mathrm{a}$ & $36.81 \mathrm{~b}$ & $9.49 \mathrm{~d}$ & $5.55 \mathrm{c}$ & $9.97 \mathrm{~b}$ \\
\hline EL-Menufia & $5.32 \mathrm{e}$ & $6.20 \mathrm{e}$ & $3.12 \mathrm{~b}$ & $36.77 \mathrm{~b}$ & $9.13 \mathrm{e}$ & $5.33 \mathrm{~d}$ & $5.32 \mathrm{e}$ \\
\hline L.S.D. : 0.01 & 0.679 & 0.811 & 0.044 & 0.229 & 0.096 & 0.076 & 0.679 \\
\hline
\end{tabular}

With respect to boll weight (g), the results showed that the highest values of boll weight were $3.30,3.27$ and $3.27 \mathrm{~g}$. for the cotton cultivars grown at Domietta, ElBeheira and El-Dakahlia governorates, respectively, without significant differences between them. Whereas, the lowest value of boll weight was $3.11 \mathrm{~g}$. for the cotton cultivars grown at El-Sharkeia governorate.

With regard to lint percentage (g), it could be concluded that, the highest value of lint percentage was produced at Kafr El-Sheikh governorate (37.17\%), but the lowest value was produced at El-Gharbia governorate (36.33\%). The other locations did not significantly differed with respect to lint percentage.

With reference to seed index (g), it could be observed that, the highest value of seed index (g) was produced at ElBeheira and Kafr El-Sheikh governorate where its values were 10.16 and $10.13 \mathrm{~g}$, respectively. However, the lowest value was produced at El-Menufia governorate 9.13g.
With respect to lint index (g), it could be observed from the data listed in Table (4) that the highest value of lint index (g) was produced at Kafr El-Sheikh governorate $(6.00 \mathrm{~g})$, but the lowest value was produced at El-Menufia governorate (5.33 g).

These results are confirmed by the findings of Al-Hibbiny (2004), Hassan et al. (2005), Rahoumah et al. (2008), Shaker (2009), Shaker (2014), Abdel-Aziz, Eman (2015), Abd El-Samee (2015) and ElGanainy, Hanan (2017). Where they reported that, the effect of locations had significant on most previous studied characters.

\subsection{Seasons mean performance:}

The data in Table (5) suggested that, seed and lint cotton yields, boll weight and lint index were insignificantly variable across seasons, while the remains characters i.e., lint percentage and seed index showed highly significant differences across seasons. The highest mean values of lint percentage and seed index occurred in the second season (2015). 
Table (5): Mean performance of seasons for cotton yield, yield components and fiber properties over seven locations.

\begin{tabular}{|c|c|c|c|c|c|c|}
\hline $\begin{array}{c}\text { Growing } \\
\text { seasons }\end{array}$ & $\begin{array}{c}\text { Seed } \\
\text { cotton } \\
\text { yield (K/F) }\end{array}$ & $\begin{array}{c}\text { Lint cotton } \\
\text { (yield K/F) }\end{array}$ & $\begin{array}{c}\text { Boll weight } \\
(\mathrm{g})\end{array}$ & $\begin{array}{c}\text { Lint } \\
\text { percentage } \\
\%\end{array}$ & $\begin{array}{c}\text { Seed index } \\
(\mathrm{g})\end{array}$ & $\begin{array}{c}\text { Lint index } \\
(\mathrm{g})\end{array}$ \\
\hline 2014 & 8.93 & 9.34 & 3.21 & 36.55 & 9.70 & 5.60 \\
\hline 2015 & 8.99 & 9.50 & 3.21 & 37.02 & 9.76 & 5.75 \\
\hline F-test & n.s. & n.s. & n.s. & $* *$ & $* *$ & n.s. \\
\hline
\end{tabular}

In this respect, Shaker (2009), Hassan et al. (2012 c), Hassan et al., (2013), Linghe et al. (2014) and El-Ganainy, Hanan (2017) supported the obtained results.

\subsection{Effect of the interaction between seasons and locations:}

Results listed in Table (6) illustrated that, the interaction between seasons and locations showed that, the significantly greatest seed cotton yield and lint cotton yield (k/f) were obtained at El-Gharbia governorate in the second season, followed by Kafr El-Sheikh in the first season and El-Dakahlia in the first season with significant differences between the three interactions. While, the lowest seed cotton and lint cotton yields were yielded at El-Menufia governorate in the first season (4.54 and $5.16 \mathrm{k} / \mathrm{f}$ ), respectively.

Concerning to boll weight (g), the highest values were obtained at ElGharbia in the second season, Domietta in the first season, Kafr El-Sheikh in the first season, El- Dakahlia in the first season with no significant differences between these interactions. On the contrary, ElSharkeia in the second season and ElMenufia governorate in the first season showed the lowest value of boll weight $(3.03 \mathrm{~g})$, with no significant differences between them.
The greatest lint percentage were produced at El-Menufia in the second season (37.53\%) and at Kafr El-Sheikh in the first season (37.33\%), with no significant difference between them, followed by Domietta, El-Dakahlia, ElBeheira and Kafr El-Sheikh in the second season, where there was no significant differences between these interactions with respect to the trait in view. While, ElMenufia in the first season gave the lowest lint percentage.

With respect to seed index (g), Domietta in the second season, Kafr ElSehikh in the first season and El-Beheira in the second season produced the greatest values $(10.38,10.33$ and $10.25 \mathrm{~g}$, respectively) and came in the first grad in this concern with no significant differences between them. On the other hand, the lowest value of seed index (9.07 g) was produced at El-Menufia in the first season.

These results are in agreatment with those reviewed by Hassan et al. (2005), Rahoumah et al (2008), Shaker (2009), Shaker et al. (2013), Shaker (2014), AbdelAziz, Eman (2015) and El-Ganainy, Hanan (2017) where they reported that, the effect of environmental conditions were different from location to another and from season to another. 
Table (6): Effect of the interaction between cotton growing locations and growing seasons on yield and yield components over seven locations and two seasons, (2014 and 2015).

\begin{tabular}{|c|c|c|c|c|c|c|}
\hline \multicolumn{2}{|c|}{$\begin{array}{c}\text { Interaction between } \\
\text { locations x seasons }\end{array}$} & $\begin{array}{c}\text { Seed } \\
\text { cotton } \\
\text { yield (K/F) }\end{array}$ & $\begin{array}{c}\text { Lint } \\
\text { cotton } \\
\text { yield K/F) }\end{array}$ & $\begin{array}{c}\text { Boll } \\
\text { weight (g) }\end{array}$ & $\begin{array}{c}\text { Lint } \\
\text { percentage } \\
\%\end{array}$ & $\begin{array}{c}\text { Seed } \\
\text { index (g) }\end{array}$ \\
\hline \hline \multirow{2}{*}{ Kafr El-Sheikh } & 2014 & 14.34 & 16.85 & 3.34 & 37.33 & 10.33 \\
\cline { 2 - 7 } & 2015 & 8.69 & 10.13 & 3.17 & 37.00 & 9.92 \\
\hline \multirow{2}{*}{ El-Gharbia } & 2014 & 4.94 & 5.60 & 2.99 & 36.02 & 9.18 \\
\cline { 2 - 7 } & 2015 & 17.48 & 20.23 & 3.35 & 36.63 & 10.13 \\
\hline \multirow{2}{*}{ Domietta } & 2014 & 8.77 & 10.12 & 3.35 & 36.59 & 9.69 \\
\cline { 2 - 7 } & 2015 & 8.25 & 9.65 & 3.26 & 37.18 & 10.38 \\
\hline \multirow{3}{*}{ El-Sharkeia } & 2014 & 9.84 & 11.47 & 3.18 & 36.98 & 9.78 \\
\cline { 2 - 7 } & 2015 & 5.53 & 6.39 & 3.05 & 36.61 & 9.21 \\
\hline \multirow{2}{*}{ EL-Beheira } & 2014 & 8.98 & 10.30 & 3.34 & 36.44 & 10.07 \\
\cline { 2 - 7 } & 2015 & 8.04 & 9.52 & 3.20 & 37.06 & 10.25 \\
\hline \multirow{2}{*}{ EL-Dakahlia } & 2014 & 11.08 & 12.72 & 3.32 & 36.52 & 9.77 \\
\cline { 2 - 7 } & 2015 & 8.85 & 10.34 & 3.24 & 37.10 & 9.22 \\
\hline \multirow{2}{*}{ EL-Menufia } & 2014 & 4.54 & 5.16 & 3.03 & 36.00 & 9.07 \\
\cline { 2 - 7 } & 2015 & 6.10 & 7.25 & 3.22 & 37.53 & 9.18 \\
\hline L.S.D. : 0.01 & & 0.961 & 1.147 & 0.062 & 0.324 & 0.136 \\
\hline
\end{tabular}

\subsection{Effect of the interaction} between cultivars and seasons:

The data listed in Table (7) revealed that, the cotton cultivars; Giza 86, Giza 94 and Giza 87 in the first season, and the cultivars; Giza 88, Giza 92 and Giza 93 in the second season had the highest values of seed cotton yield with no significant differences between these interactions. On the other hand, the extra long stable Giza 96 cultivar in the first season and Giza 45 in the second season recognized the lowest values of the traits in view with no significant difference between the two interactions in this concern.

With regard to lint cotton yield, the data shown in table 7 illustrated that, Giza 86 and Giza 87 in the first season and Giza 88, Giza 92, Giza 93 and Giza 96 in the second season gave the highest values with no significant difference in this respect. Whereas, the lowest lint cotton yield was produced by the extra long stable Giza 45 cultivars in the second season and Giza 96 in the first season, however, there is no significant difference between the two interactions in this respect.

Results of lint percentage (\%) in Table (7) revealed that, the cultivar Giza 96 had the highest value $(39.07 \%)$ during the first and second seasons, followed by the same cultivar in the first season with significant between them. On the other side, the lowest values were 35.21 and $35.19 \%$ for Giza 45 in the first and second seasons, respectively. 
R. A. El-Refaey, et al.,

Table (7): Effect of the interaction between cotton cultivars and growing seasons on yield, and yield components over seven locations and two seasons, (2014 and 2015).

\begin{tabular}{|c|c|c|c|c|c|c|c|}
\hline \multicolumn{2}{|c|}{$\begin{array}{c}\text { Interaction } \\
\text { between } \\
\text { cultivars x seasons }\end{array}$} & $\begin{array}{c}\text { Seed } \\
\text { cotton } \\
\text { yield (K/F) }\end{array}$ & $\begin{array}{c}\text { Lint cotton } \\
\text { yield } \\
\text { (K/F) }\end{array}$ & $\begin{array}{c}\text { Boll } \\
\text { weight } \\
\text { (g) }\end{array}$ & $\begin{array}{c}\text { Lint } \\
\text { percentage } \\
\%\end{array}$ & $\begin{array}{c}\text { Seed } \\
\text { index (g) }\end{array}$ & $\begin{array}{c}\text { Lint } \\
\text { index (g) }\end{array}$ \\
\hline \hline \multirow{2}{*}{ Giza 86 } & 2014 & 10.39 & 12.11 & 3.36 & 36.86 & 10.17 & 5.95 \\
\cline { 2 - 8 } & 2015 & 8.99 & 10.55 & 3.34 & 37.33 & 10.07 & 6.00 \\
\hline \multirow{3}{*}{ Giza 94 } & 2014 & 9.53 & 10.85 & 3.12 & 36.14 & 9.01 & 5.10 \\
\cline { 2 - 8 } & 2015 & 8.29 & 9.41 & 3.14 & 36.09 & 9.10 & 5.14 \\
\hline \multirow{3}{*}{ Giza 45 } & 2014 & 8.15 & 9.09 & 2.83 & 35.21 & 8.81 & 4.80 \\
\cline { 2 - 8 } & 2015 & 7.36 & 8.16 & 2.83 & 35.19 & 8.76 & 4.75 \\
\hline \multirow{3}{*}{ Giza 87 } & 2014 & 9.57 & 11.22 & 3.33 & 36.99 & 10.11 & 5.95 \\
\cline { 2 - 8 } & 2015 & 8.31 & 9.85 & 3.34 & 37.75 & 10.16 & 6.17 \\
\hline \multirow{3}{*}{ Giza 88 } & 2014 & 8.87 & 10.14 & 3.24 & 36.11 & 9.69 & 5.49 \\
\cline { 2 - 8 } & 2015 & 9.71 & 11.22 & 3.25 & 36.83 & 9.77 & 5.70 \\
\hline \multirow{2}{*}{ Giza 92 } & 2014 & 8.70 & 9.91 & 3.19 & 36.13 & 9.74 & 5.50 \\
\cline { 2 - 8 } & 2015 & 9.85 & 11.40 & 3.18 & 36.80 & 9.81 & 5.71 \\
\hline \multirow{2}{*}{ Giza 93 } & 2014 & 8.94 & 10.32 & 3.39 & 36.50 & 10.41 & 6.00 \\
\cline { 2 - 8 } & 2015 & 10.08 & 11.90 & 3.37 & 37.06 & 10.68 & 6.29 \\
\hline \multirow{2}{*}{ Giza 96 } & 2014 & 7.26 & 8.90 & 3.26 & 38.52 & 9.62 & 6.03 \\
\cline { 2 - 8 } & 2015 & 9.33 & 11.52 & 3.22 & 39.07 & 9.69 & 6.22 \\
\hline L.S.D. : 0.01 & & 1.027 & 1.226 & - & 0.347 & 0.145 & 0.114 \\
\hline
\end{tabular}

Concerning seed index, the highest value was recorded by Giza 93 (10.68) in the second season, followed by the same cultivar in the first season (10.41). While, the lowest values were 8.81 and $8.76 \mathrm{~g}$ for Giza 45 in the first and second seasons, respectively.

The significant interaction between cultivars and seasons explained that these two factors are dependable on each other in their influence on yield components.

The present results are in the same trend with the findings obtained by AbdelHafez et al. (2000), El-Adly and Eissa (2010), Abdel-Aziz, Eman (2015), Abd El Samad et al. (2017), El-Ganainy, Hanan (2017) and Shaker (2017).

\subsection{Effect of the interaction between cultivars and locations:}

The data shown in Table (8) revealed that the average values of seed cotton and lint cotton yields, were identically.Highly significant differences were obtained by growing Giza 92 , Giza 93 and Giza 86 at Kafr El-Sheikh governorate and Giza 88 at El-Gharbia governorate with no significant differences between these cultivar $x$ location interactions. While, the lowest values were recorded by growing cotton cultivars; Giza 45, Giza 87, Giza 94, Giza 88, Giza 92 and Giza 96 at El-Menufia location.

For boll weight, the results indicated that highly significant differences boll 
weight values were obtained by growing Giza 96, Giza 86 and Giza 93 at Domietta location; Giza 93 Giza 86 and Giza 87 at Kafr El-Sheikh location; Giza 93 at ELGharbia location and Giza 96 at El-Beheira location with no significant differences between these interactions for the trait in view. On the other hand, the lowest values of boll weight were observed by sowing Giza 45 at EL-Sharkiea and Giza 45 at ElMenufia location with no significant differences between the two interactions in this concern.

Table (8): Effect of the interaction between cotton cultivars and locations over seasons on yield and yield component

\begin{tabular}{|c|c|c|c|c|c|c|c|}
\hline \multicolumn{8}{|c|}{ Seed cotton yield (K/F) } \\
\hline Cultivars & $\begin{array}{c}\text { Kafr El- } \\
\text { Sheikh }\end{array}$ & $\begin{array}{c}\text { El- } \\
\text { Gharbia }\end{array}$ & Domietta & $\begin{array}{c}\text { El- } \\
\text { Sharkeia }\end{array}$ & $\begin{array}{c}\text { EL- } \\
\text { Beheira }\end{array}$ & $\begin{array}{c}\text { EL- } \\
\text { Dakahlia }\end{array}$ & $\begin{array}{c}\text { EL- } \\
\text { Menufia }\end{array}$ \\
\hline Giza 86 & 12.43 & 12.14 & 8.34 & 8.64 & 8.69 & 11.41 & 6.10 \\
\hline Giza 94 & 9.48 & 12.09 & 9.25 & 7.10 & 9.62 & 9.97 & 4.87 \\
\hline Giza 45 & 10.71 & 7.82 & 10.44 & 4.72 & 6.02 & 10.12 & 4.46 \\
\hline Giza 87 & 10.33 & 11.15 & 7.96 & 9.07 & 7.35 & 11.27 & 5.47 \\
\hline Giza 88 & 11.34 & 12.36 & 8.14 & 9.45 & 9.30 & 9.52 & 4.97 \\
\hline Giza 92 & 14.17 & 11.36 & 6.90 & 6.82 & 10.27 & 10.41 & 5.00 \\
\hline Giza 93 & 12.82 & 11.00 & 8.40 & 9.33 & 9.15 & 10.00 & 6.68 \\
\hline Giza 96 & 10.83 & 11.79 & 8.52 & 6.38 & 7.69 & 6.25 & 5.04 \\
\hline L.S.D.: 0.01 & \multicolumn{7}{|c|}{1.922} \\
\hline \multicolumn{8}{|c|}{ Lint cotton yield K/F) } \\
\hline Giza 86 & 14.75 & 13.94 & 9.90 & 10.12 & 10.08 & 13.33 & 7.19 \\
\hline Giza 94 & 10.85 & 13.55 & 10.59 & 8.01 & 11.03 & 11.33 & 5.56 \\
\hline Giza 45 & 12.14 & 8.61 & 11.61 & 5.28 & 6.76 & 11.13 & 4.87 \\
\hline Giza 87 & 12.46 & 12.92 & 9.37 & 10.67 & 8.62 & 13.30 & 6.43 \\
\hline Giza 88 & 13.23 & 14.09 & 9.58 & 10.81 & 10.52 & 10.90 & 5.68 \\
\hline Giza 92 & 16.23 & 13.01 & 7.84 & 7.99 & 11.78 & 11.84 & 5.88 \\
\hline Giza 93 & 14.88 & 12.70 & 9.66 & 10.87 & 10.98 & 12.08 & 8.01 \\
\hline Giza 96 & 13.40 & 14.50 & 10.56 & 7.73 & 9.54 & 7.32 & 6.03 \\
\hline L.S.D.: 0.01 & & & & 2.293 & & & \\
\hline \multicolumn{8}{|c|}{$\frac{2.293}{\text { Boll weight (g) }}$} \\
\hline Giza 86 & 3.44 & 3.30 & 3.39 & 3.25 & 3.32 & 3.44 & 3.32 \\
\hline Giza 94 & 3.27 & 3.06 & 3.22 & 2.89 & 3.25 & 3.28 & 3.00 \\
\hline Giza 45 & 2.79 & 2.87 & 2.97 & 2.72 & 2.92 & 2.86 & 2.72 \\
\hline Giza 87 & 3.37 & 3.33 & 3.37 & 3.32 & 3.32 & 3.38 & 3.28 \\
\hline Giza 88 & 3.27 & 3.21 & 3.33 & 3.21 & 3.25 & 3.32 & 3.17 \\
\hline Giza 92 & 3.25 & 3.08 & 3.25 & 3.05 & 3.34 & 3.24 & 3.08 \\
\hline Giza 93 & 3.45 & 3.39 & 3.38 & 3.33 & 3.34 & 3.37 & 3.34 \\
\hline Giza 96 & 3.20 & 3.09 & 3.49 & 3.14 & 3.42 & 3.08 & 3.12 \\
\hline L.S.D.: 0.01 & \multicolumn{7}{|c|}{0.124} \\
\hline
\end{tabular}


R. A. El-Refaey, et al.,

Table (8): Cont.

\begin{tabular}{|c|c|c|c|c|c|c|c|}
\hline \multicolumn{7}{|c|}{ Lint percentage \% } \\
\hline Cultivars & $\begin{array}{c}\text { Kafr El- } \\
\text { Sheikh }\end{array}$ & $\begin{array}{c}\text { El- } \\
\text { Gharbia }\end{array}$ & Domietta & $\begin{array}{c}\text { El- } \\
\text { Sharkeia }\end{array}$ & $\begin{array}{c}\text { EL- } \\
\text { Beheira }\end{array}$ & $\begin{array}{c}\text { EL- } \\
\text { Dakahlia }\end{array}$ & $\begin{array}{c}\text { EL- } \\
\text { Menufia }\end{array}$ \\
\hline Giza 86 & 37.58 & 36.35 & 37.08 & 37.04 & 36.97 & 37.19 & 37.48 \\
\hline Giza 94 & 36.35 & 35.55 & 36.36 & 35.77 & 36.46 & 36.16 & 36.17 \\
\hline Giza 45 & 35.96 & 34.61 & 35.30 & 35.40 & 35.53 & 34.93 & 34.68 \\
\hline Giza 87 & 38.16 & 36.64 & 37.25 & 37.24 & 37.33 & 37.59 & 37.40 \\
\hline Giza 88 & 36.97 & 35.87 & 37.49 & 36.38 & 35.97 & 36.44 & 36.19 \\
\hline Giza 92 & 36.48 & 36.09 & 35.89 & 37.26 & 36.40 & 36.09 & 37.05 \\
\hline Giza 93 & 36.72 & 36.69 & 36.52 & 36.93 & 36.08 & 36.62 & 37.69 \\
\hline Giza 96 & 39.14 & 38.86 & 39.22 & 38.34 & 39.27 & 36.96 & 37.51 \\
\hline L.S.D. : 0.01 & & & 0.649 & & & \\
\hline \hline & & & & & & \\
\hline Giza 86 & 10.81 & 9.76 & 10.46 & 9.96 & 10.33 & 10.09 & 9.49 \\
\hline Giza 94 & 9.24 & 9.10 & 9.53 & 8.74 & 9.58 & 8.80 & 8.41 \\
\hline Giza 45 & 9.03 & 8.56 & 9.33 & 8.38 & 9.24 & 8.60 & 8.40 \\
\hline Giza 87 & 10.51 & 10.02 & 10.55 & 9.83 & 10.50 & 10.29 & 9.28 \\
\hline Giza 88 & 10.18 & 9.63 & 9.80 & 9.82 & 10.09 & 9.48 & 9.17 \\
\hline Giza 92 & 10.10 & 9.78 & 9.97 & 9.64 & 10.23 & 9.45 & 9.29 \\
\hline Giza 93 & 11.22 & 10.83 & 10.92 & 10.37 & 10.92 & 10.60 & 9.85 \\
\hline Giza 96 & 9.95 & 9.60 & 9.74 & 9.28 & 10.40 & 9.45 & 9.17 \\
\hline L.S.D. : 0.01 & & & 0.271 \\
\hline
\end{tabular}

For lint percentage the significantly highest values were recorded when growing Giza 96 cultivar at El-Beheira, Kafr ELSheikh, Domietta and El-Gharbia locations with no significant differences between these interactions. While the lowest values of the trait in question were obtained by sowing Giza 45 cultivar at El-Gharbi, El-Menufia, El-Dekahlia, ElSharkiea and El-Beheira governorates with no significant difference between these interactions.

With respect to seed index, the results pointed out that, the significantly highest value was obtained with sowing Giza 93 cultivar at kafr El-Sheikh location. While, the lowest value was recorded when growing Giza 45 cultivar at El-Gharbia location with significant differences between the first interaction or the second one with respect to the other interactions.

In this connection, the obtained results are supported by Hassan et al. (2013 a) who illustrated that adaptation to different environments was high for the promising strain [Giza 84 (Giza 70 x Giza 51b)] x Pima S62 and the commercial cultivar Giza 92 at El-Gharbia governorate for most traits. The promising strain of long staple (10229 $x$ Giza 92 86) exceeded the commercial cultivar Giza 86 for all studied traits at ElSharkia governorate. 
2.7. Effect of the interaction between cultivars, locations and growing seasons:

Table (9) showed that the mean values of seed cotton yield and some of its components, as affected by the second order interaction; cultivars $\times$ locations $x$ seasons.

Data presented in Table (9) pointed out that, Giza 88, Giza 92, Giza 93 and Giza 86 produced the highest values of the seed cotton yield at El-Gharbia governorate in the second season (2015), with no significant differences between these second order interactions. While, the lowest values of seed cotton yield were obtained for all cultivars used in the study at El-Menufia location in the first season (2014), without significant differences between these interactions in this concern.

Table (9): Effect of the interaction between cotton genotypes, locations and growing seasons on yield and yield component

\begin{tabular}{|c|c|c|c|c|c|c|c|c|c|c|c|c|c|c|}
\hline \multicolumn{15}{|c|}{ Seed cotton yield (K/F) } \\
\hline Genotype & \multicolumn{2}{|c|}{$\begin{array}{l}\text { Kafr El- } \\
\text { Sheikh }\end{array}$} & \multicolumn{2}{|c|}{ El-Gharbia } & \multicolumn{2}{|c|}{ Domietta } & \multicolumn{2}{|c|}{$\begin{array}{c}\text { El- } \\
\text { Sharkeih }\end{array}$} & \multicolumn{2}{|c|}{$\begin{array}{c}\text { EL- } \\
\text { Beheira }\end{array}$} & \multicolumn{2}{|c|}{$\begin{array}{c}\text { EL- } \\
\text { Dakahlia }\end{array}$} & \multicolumn{2}{|c|}{$\begin{array}{c}\text { EL- } \\
\text { Menufia }\end{array}$} \\
\hline seasons & 2014 & 2015 & 2014 & 2015 & 2014 & 2015 & 2014 & 2015 & 2014 & 2015 & 2014 & 2015 & 2014 & 2015 \\
\hline Giza 86 & 15.34 & 9.51 & 5.77 & 18.50 & 8.18 & 8.79 & 12.14 & 5.13 & 11.43 & 5.94 & 13.78 & 9.04 & 6.13 & 6.06 \\
\hline Giza 94 & 12.94 & 6.01 & 7.00 & 17.17 & 8.75 & 9.74 & 9.76 & 4.44 & 12.35 & 6.89 & 11.78 & 8.15 & 4.09 & 5.65 \\
\hline Giza 45 & 13.65 & 7.77 & 4.06 & 11.58 & 10.39 & 10.49 & 6.05 & 3.39 & 6.35 & 5.69 & 12.25 & 7.98 & 4.31 & 4.61 \\
\hline Giza 87 & 13.03 & 7.63 & 5.46 & 16.83 & 7.49 & 8.43 & 11.94 & 6.19 & 9.49 & 5.21 & 13.74 & 8.79 & 5.87 & 5.06 \\
\hline Giza 88 & 13.62 & 9.06 & 4.43 & 20.28 & 8.61 & 7.66 & 12.04 & 6.86 & 9.18 & 9.41 & 10.14 & 8.89 & 4.10 & 5.83 \\
\hline Giza 92 & 16.24 & 12.10 & 4.66 & 18.05 & 8.74 & 5.06 & 7.02 & 6.62 & 9.36 & 11.17 & 11.24 & 9.57 & 3.61 & 6.38 \\
\hline Giza 93 & 16.39 & 9.25 & 4.17 & 17.82 & 8.68 & 8.12 & 12.37 & 6.28 & 7.23 & 11.07 & 8.92 & 9.50 & 4.84 & 8.52 \\
\hline Giza 96 & 13.50 & 8.16 & 3.96 & 19.61 & 9.31 & 7.72 & 7.44 & 5.32 & 6.45 & 8.93 & 6.81 & 8.89 & 3.37 & 6.71 \\
\hline L.S.D.:0.01 & \multicolumn{14}{|c|}{2.718} \\
\hline \multicolumn{15}{|c|}{ Lint cotton yield K/F) } \\
\hline Genotype & \multicolumn{2}{|c|}{$\begin{array}{l}\text { Kafr El- } \\
\text { Sheikh }\end{array}$} & \multicolumn{2}{|c|}{ El-Gharbia } & \multicolumn{2}{|c|}{ Domietta } & \multicolumn{2}{|c|}{$\begin{array}{c}\text { El- } \\
\text { Sharkeih }\end{array}$} & \multicolumn{2}{|c|}{$\begin{array}{c}\text { EL- } \\
\text { Beheira }\end{array}$} & \multicolumn{2}{|c|}{$\begin{array}{c}\text { EL- } \\
\text { Dakahlia }\end{array}$} & \multicolumn{2}{|c|}{$\begin{array}{c}\text { EL- } \\
\text { Menufia }\end{array}$} \\
\hline seasons & 2014 & 2015 & 2014 & 2015 & 2014 & 2015 & 2014 & 2015 & 2014 & 2015 & 2014 & 2015 & 2014 & 2015 \\
\hline Giza 86 & 18.32 & 11.17 & 6.56 & 21.32 & 9.42 & 10.38 & 14.32 & 5.92 & 13.15 & 7.00 & 15.92 & 10.73 & 7.09 & 7.29 \\
\hline Giza 94 & 14.85 & 6.85 & 7.82 & 19.28 & 10.18 & 11.00 & 11.02 & 4.99 & 14.09 & 7.96 & 13.30 & 9.36 & 4.67 & 6.45 \\
\hline Giza 45 & 15.46 & 8.81 & 4.35 & 12.86 & 11.70 & 11.52 & 6.80 & 3.76 & 7.15 & 6.36 & 13.50 & 8.75 & 4.67 & 5.07 \\
\hline Giza 87 & 15.78 & 9.13 & 6.27 & 19.57 & 8.55 & 10.18 & 14.17 & 7.17 & 11.00 & 6.24 & 16.04 & 10.56 & 6.74 & 6.12 \\
\hline Giza 88 & 16.01 & 10.44 & 4.93 & 24.25 & 9.97 & 9.19 & 13.71 & 7.90 & 10.27 & 10.76 & 11.49 & 10.30 & 4.61 & 6.74 \\
\hline Giza 92 & 18.40 & 14.06 & 5.22 & 20.80 & 9.92 & 5.75 & 8.11 & 7.87 & 10.76 & 12.80 & 12.89 & 10.79 & 4.05 & 7.70 \\
\hline Giza 93 & 19.13 & 10.62 & 4.81 & 20.59 & 9.80 & 9.51 & 14.50 & 7.23 & 8.11 & 13.85 & 10.30 & 11.05 & 5.57 & 10.44 \\
\hline Giza 96 & 16.83 & 9.97 & 4.81 & 24.18 & 11.43 & 9.68 & 9.16 & 6.30 & 7.87 & 11.20 & 8.28 & 11.17 & 3.88 & 8.17 \\
\hline L.S.D.:0.01 & \multicolumn{14}{|c|}{3.243} \\
\hline
\end{tabular}


R. A. El-Refaey, et al.,

Table (9): Cont.

\begin{tabular}{|c|c|c|c|c|c|c|c|c|c|c|c|c|c|c|}
\hline \multicolumn{15}{|c|}{ Lint percentage \% } \\
\hline Genotype & \multicolumn{2}{|c|}{$\begin{array}{l}\text { Kafr El- } \\
\text { Sheikh }\end{array}$} & \multicolumn{2}{|c|}{ El-Gharbia } & \multicolumn{2}{|c|}{ Domietta } & \multicolumn{2}{|c|}{ El-Sharkeih } & \multicolumn{2}{|c|}{ EL- Beheira } & \multicolumn{2}{|c|}{ EL- Dakahlia } & \multicolumn{2}{|c|}{ EL- Menufia } \\
\hline seasons & 2014 & 2015 & 2014 & 2015 & 2014 & 2015 & 2014 & 2015 & 2014 & 2015 & 2014 & 2015 & 2014 & 2015 \\
\hline Giza 86 & 37.88 & 37.28 & 36.15 & 36.55 & 36.60 & 37.55 & 37.47 & 6.60 & 36.55 & 37.38 & 36.68 & 37.70 & 36.68 & 38.27 \\
\hline Giza 94 & 36.50 & 36.20 & 35.45 & 35.65 & 36.93 & 35.78 & 35.83 & 35.70 & 36.20 & 36.72 & 35.85 & 36.47 & 36.20 & 36.13 \\
\hline Giza 45 & 35.95 & 35.97 & 34.00 & 35.22 & 35.75 & 34.85 & 35.65 & 35.15 & 35.73 & 35.33 & 35.02 & 34.83 & 34.35 & 35.00 \\
\hline Giza 87 & 38.43 & 37.88 & 36.40 & 36.88 & 36.20 & 38.30 & 37.70 & 36.78 & 36.68 & 37.98 & 37.05 & 38.13 & 36.45 & 38.35 \\
\hline Giza 88 & 37.35 & 36.58 & 35.35 & 36.38 & 36.75 & 38.22 & 36.15 & 36.60 & 35.50 & 36.43 & 35.97 & 36.90 & 35.68 & 36.70 \\
\hline Giza 92 & 36.08 & 36.88 & 35.60 & 36.85 & 36.03 & 35.75 & 36.68 & 37.83 & 36.50 & 36.30 & 36.38 & 35.80 & 35.63 & 38.47 \\
\hline Giza 93 & 37.00 & 36.43 & 36.68 & 36.70 & 35.85 & 37.18 & 37.20 & 36.65 & 35.60 & 36.55 & 36.68 & 37.05 & 36.50 & 38.88 \\
\hline Giza 96 & 39.47 & 38.80 & 38.58 & 39.13 & 38.60 & 39.83 & 39.13 & 37.55 & 38.75 & 39.78 & 38.58 & 39.95 & 36.55 & 38.47 \\
\hline L.S.D.: 0.01 & \multicolumn{14}{|c|}{0.918} \\
\hline \multicolumn{15}{|c|}{ Seed index (g) } \\
\hline Genotype & \multicolumn{2}{|c|}{$\begin{array}{c}\text { Kafr } \\
\text { El-Sheikh }\end{array}$} & \multicolumn{2}{|c|}{ El-Gharbia } & \multicolumn{2}{|c|}{ Domietta } & \multicolumn{2}{|c|}{ El-Sharkeih } & \multicolumn{2}{|c|}{ EL- Beheira } & \multicolumn{2}{|c|}{ EL- Dakahlia } & \multicolumn{2}{|c|}{ EL- Menufia } \\
\hline seasons & 2014 & 2015 & 2014 & 2015 & 2014 & 2015 & 2014 & 2015 & 2014 & 2015 & 2014 & 2015 & 2014 & 2015 \\
\hline Giza 86 & 10.88 & 10.73 & 9.33 & 10.18 & 10.23 & 10.68 & 10.48 & 9.43 & 10.22 & 10.43 & 10.53 & 9.65 & 9.58 & 9.40 \\
\hline Giza 94 & 9.50 & 8.98 & 8.70 & 9.50 & 9.08 & 9.98 & 9.05 & 8.43 & 9.43 & 9.73 & 9.05 & 8.55 & 8.27 & 8.55 \\
\hline Giza 45 & 9.25 & 8.80 & 8.23 & 8.88 & 9.00 & 9.65 & 8.55 & 8.20 & 9.27 & 9.20 & 8.90 & 8.30 & 8.50 & 8.30 \\
\hline Giza 87 & 10.63 & 10.38 & 9.40 & 10.63 & 10.42 & 10.68 & 10.13 & 9.53 & 10.45 & 10.55 & 10.53 & 10.05 & 9.25 & 9.30 \\
\hline Giza 88 & 10.33 & 10.02 & 9.23 & 10.02 & 9.35 & 10.25 & 10.18 & 9.45 & 9.90 & 10.28 & 9.80 & 9.15 & 9.08 & 9.25 \\
\hline Giza 92 & 10.45 & 9.75 & 9.13 & 10.43 & 9.60 & 10.33 & 10.05 & 9.22 & 10.20 & 10.25 & 9.52 & 9.38 & 9.25 & 9.33 \\
\hline Giza 93 & 11.23 & 11.20 & 10.25 & 11.40 & 10.53 & 11.30 & 10.48 & 10.25 & 10.73 & 11.10 & 10.10 & 9.43 & 9.60 & 10.10 \\
\hline Giza 96 & 10.38 & 9.52 & 9.18 & 10.02 & 9.33 & 10.15 & 9.35 & 9.20 & 10.35 & 10.45 & 9.70 & 9.23 & 9.08 & 9.25 \\
\hline L.S.D.:0.01 & \multicolumn{14}{|c|}{0.384} \\
\hline
\end{tabular}

With respect to lint cotton yield, the data revealed that, Giza 88 and Giza 86 cultivars had the highest values for the trait under test at El-Gharbia location in the second season without significant differences between the two second order interactions. On the other hand, all cotton cultivars in this study when sowing at ElMenufia location in the first season recorded the lowest values of the trait in 
scope with no significant difference between these interactions.

For lint percentage, the data illustrated that Giza 96 cultivar in the second season at El-Dakahlia, El-Beheira, Domietta and El-Gharbia locations, and the same cultivar in the first season at Kafr El-Sheikh and El-Sharkeia locations produced the highest lint percentages without significant differences between these interactions. While, the lowest values were obtained when sowing Giza 45 cultivar at ElGharbia and El-Menufia locations in the first season and sowing the same cultivar at El-Dakahlia and Domietta locations in the second season. However, there were no significant differences between these interactions with this respect.

The data in Table (9) pointed out that the highest values of seed index were obtained with sowing Giza 93 at ElGharbia, Domietta, Kafr El-Sheikh and ElBeheira in the second season and at Kafr El-Sheikh in the first season, without significant differences between these interactions. On the other hand, the lowest seed index values were obtained with sowing Giza 45 at El-Sharkeia, ElDakahlia and El-Menufia governorates in the second season and at El-Gharbia in the first season without significant differences between these interactions. This would indicate that, the effect of cultivars differ from location to another and from season to season there traits.

Similar trend of results were previously reached by Abdel Hafez et al. (2000), Badr and Hassan (2003), Al-Hibbiny (2004), Campbell and Jones (2005). Shaker (2009) Abd El-Bary (2013). Abdel-Aziz, Eman (2015) and El-Ganainy, Hanan (2017).

\section{CONCLUSION}

Cotton as the other field crops, is greatly influenced by many factors i.e.. seasons and locations. The importance of GE interaction has long been acknowledged since that, in the absence of GE interactions, the best cultivar in any one trial would yield more than all cultivars at all locations every year. A successful breeding program should focus effort on genotype yield level (average yield compared to standards) The obtained results pointed out that, Giza 93 cultivars had the highest values for seed cotton and lint cotton yields, boll weight and seed and lint index, followed by Giza 87 cultivars while. Giza 45 cultivars gave the lowest values for yield and all studied of yield components.

\section{REFERENCES}

Abdel-Aziz, Eman S. (2015). Biometrical evaluation of some promising Egyptian cotton cultivars under different environmental conditions. M.Sc. Thesis, Fac. Agric., Cairo Univ., Egypt.

Abd El-Bary, A.M.R. (2013). Evaluation of some Egyptian cotton cultivars under different environments. J. Plant Prod. Mansoura Univ., 4(6): 957-972.

Abdel-Hafez, A.G., H.A. El-Harony, M.A. ElHity and M.E. Abd El-Salam (2000). Variety $x$ environment interaction in Egyptian cotton for yield, yield components and fiber properties. $J$. Agric. Sci. Mansoura Univ., 25 (7): 3781-3792.

Abd El-Samee, A.A. (2015). Genotypic stability and evaluation of some Egyptian cotton cultivars and fiber properties. M.Sc. Faculty of Agriculture, Al-Azhar University, Assiut, Egypt.

Abd El Samad, H.S., A.A. El Hosary, El.S. M.H. Shokr, M.E. El-Badawy, A.E.M. Eissa and A.A.A. El Hosary (2017). Selecting high yield and quality cotton cultivars using phenotypic and genotypic stability statistics. Egypt. J. Pant Breed. The $11^{\text {th }}$ international Plant 
Breeding Conf. 17 - 18 October 2017. Special issue Part (1). 21 (5): 642-653.

Al-Hibbiny, Y.I.M. (2004). Relation between the factors affecting boll opening and cotton yield and quality in Egyptian cotton. M.Sc. Thesis, Fac. of Agric., AlAzhar Univ., Egypt.

Ali, E. Samia, Eman M.R.M. Saleh and M.S.M. Srour (2012). Evaluation of some long staple cotton strains under different environments. Egypt. J. Plant Breed., 16 (1): 41 - 50.

Badr, S.S.M. and I.S.M. Hassan (2003). Evaluation of some Egyptian cotton cultivars at new location at Kafr ElSheikh. Proc. 10 ${ }^{\text {th }}$ conf. Agron. Suez Canal Univ. Fac. Environ. Agric. Sci. ElArish, Egypt, 7-10 Oct.: 1188-1203.

Badr, S.S.M. and Soad A. El-Sayed (2004). Evaluation of some long staple Egyptian cotton cultivars for yield, seed quality and seed viability characters. J. Agric. Res. Tanta Univ., 30 (2): 304-326.

Bartlett, M.S. (1937). Properties of sufficing and statistical Test. Proc. Roy. Soc. London, Series A, 160: 268 282.

Campbell, B.T. and M.A. Jones (2005). Assessment of cultivar $x$ environment interactions for yield and fiber quality in cotton performance trials. Euphytica 144: $69-78$.

El-Adly, H.H. and A.E.M. Eissa (2010). Estimate of genotypic variance and covariance components in some Egyptian cotton cultivars. Egypt. J. of Appl. Sc., 25 (3): 80 - 90.

El-Ganainy, Hanan A.E. (2017). Evaluation of some Egyptian cotton cultivars in different locations differed in type of soil and quality of irrigation water. Ph. D. Thesis, Tanta Univ. Fac Agric. Egypt.

Hassan, I.S.M. (2000). Evaluation of two new Extra long staple cotton cultivars and three commercial cultivars grown at North Delta. Annals of Agric. Sc., Moshtohor. 38 (4): 1839-1846.

Hassan, I.S.M., Amal S. Mohamed and Laila M.A. Abdel-Rahman (2005). Comparative study on seed cotton yield, oil and protein contents in the seed of some Egyptian cotton cultivars grown at different locations. Egypt. J. Agric. Res. 83 (2): 735-750.

Hassan, I.S.M., H.A. Idris and S.S.M. Badr (2012). Comparative evaluation of three promising strins and Egyptian cotton extra long staple commercial cultivars grown at different locations. Egypt. J. Agric. Res., 90 (4): 1617-1632.

Hassan, I.S.M., H.B. Abou Tour and S.S. Badr (2006). Evaluation of two new extra long staple cotton varieties with commercial cultivars grown in North Delta. Egypt. J. Agric. Res. 84 (5): 15611576.

Hassan, I.S.M., S.S.M. Badr, S.M. Seyam, Liala M.A. Abd El- Rahman and H.B.I. Abou Tour (2013). Evaluation of some new promising strains and Egyptian cotton commercial cultivars grown at different locations. Egypt. J. Agric. Res., 90 (3): 1025-1039.

Le-Clerg, E.L., W.H. Leoneard and A.G. Clark (1962). Field plot technique. Burges publishing Co., Minneapolis.

Mcintosh, M.S. (1983). Analysis of combined experiments. Agron. J., 75: 153-155.

Miller, P.A., J.C. Williams and H.F. Robinson (1959). Variety X environment interactions in cotton variety tests and their implications on testing methods. Agron. J., 51: 132135.

Mohamed, S.A.S., H.H. Al-Adly and A.E.M. Eissa (2003). Evaluation of some Egyptian cotton cultivars under different invironments

Orabi, M.H.M. (2013). Genetical Evaluation of some long staple cotton strains 
under different environments. Alex. International Cotton Conf. 10 -11 April Al-Azhar J. Agric. Res., 26, 403 - 416.

Rahoumah, M.R.A., A.M.R. Abd El-Bary, H.M. Hamoud and W.M.B. Yehia (2008). Assessment of genetic diversity and stability for yield traits of some Egyptian long-staple cotton cultivars. Egypt. J. Agric. Res., 86 (4): 1447-1462.

Shaker, S. (2009). Genotypic stability and evaluation of some Egyptian cotton cultivars. Ph. D. Thesis, fac. Of Agric. Kafr El-Sheikh Univ., Egypt.

Shaker, S.A. (2014). Comparative evaluation of two Egyptian extra long staple promising lines with cultivated commercial cotton varieties grown at
Delta. J. Agric. Res., Kafrelsheikh Univ. 40(1): 27-44.

Shaker, S.A. (2017a). Cultivar X Environment interaction for some cotton cultivars (G. Barbadense L.) under different environmental conditions. Egypt. J. Pant Breed. 21 (5) 629-641.

Shaker, S.A., S.S.M. Badr and I.S.M. Hassan (2013). Comparative evaluation of promising strain IG87 (G.45 x S.I.) with some Egyptian cotton cultivars at different locations in Delta Egypt. Egypt J. Plant Breed. 17(2): 407-421.

Snedecor, G.W. and W.G. Cochran (1982). Statistical Methods. The IOWA State Univ. Press. Ames. IOWA, USA. 
قياس التفاعل بين التراكيب الوراثية والبيئة للمحصول وبعض مكوناته لبعض أصناف القطن المصرى

رمضان على أحمد الرفاعى(") ، محمد محمود محمد عواد()، أمجد عبد الغفار الجمال(') ، محمد فتحى حامد محمد) (1) (1) (1) ملية الزراعة - جامعة طنطا

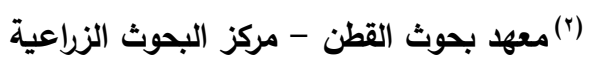
الملخص العربى تهاف هذه الدارة إلى تقييم ثماني تراكيب وراثية في بيئات مختلفة لمعرفه أفضل هذه التراكيب الوراثية لكل منطقة

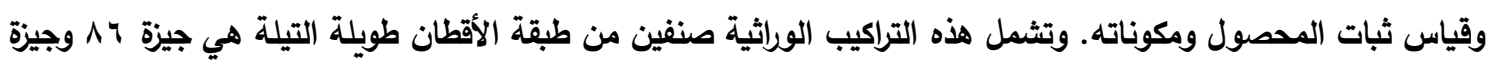

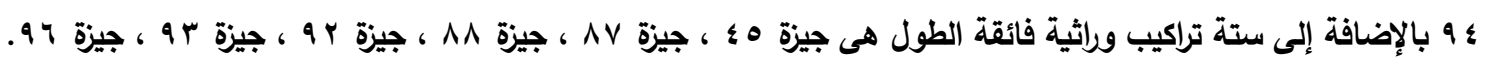

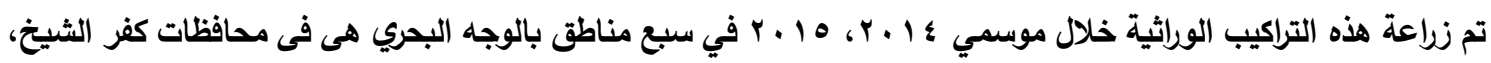

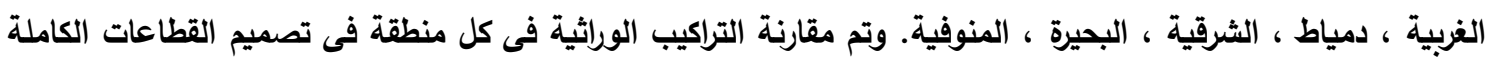

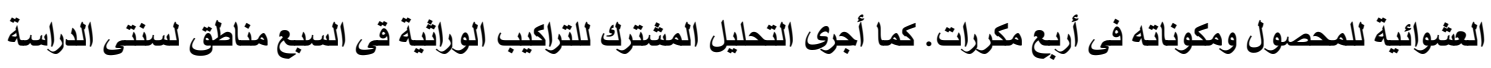

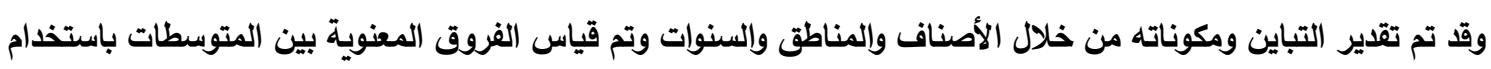

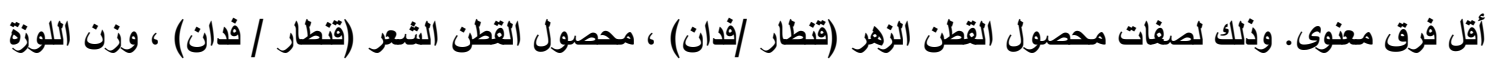

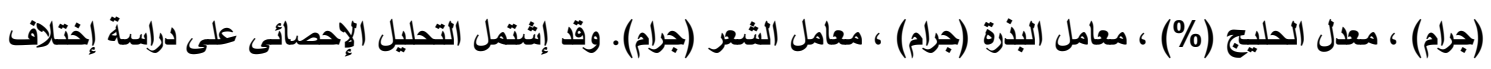

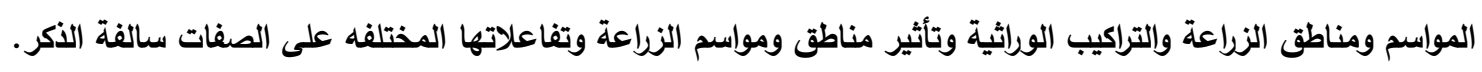

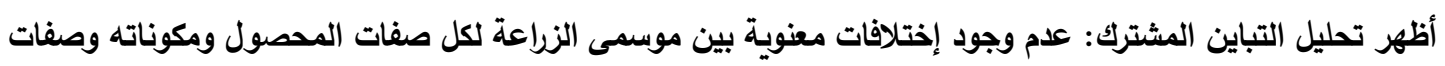

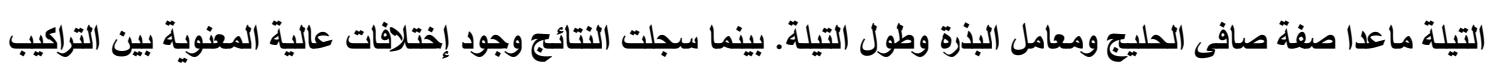

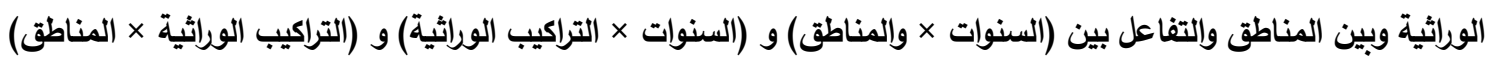

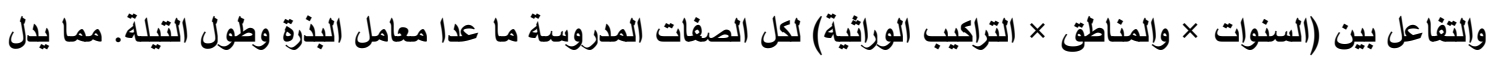

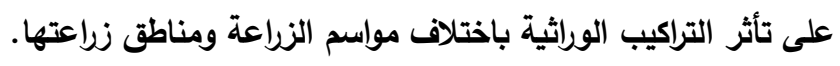

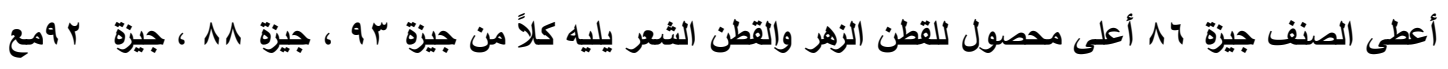

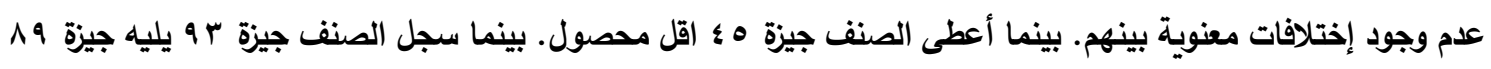

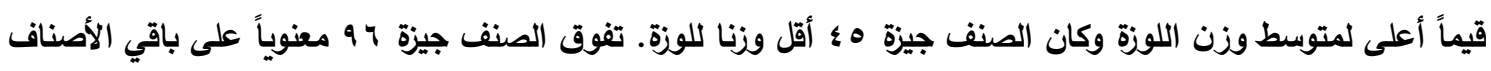

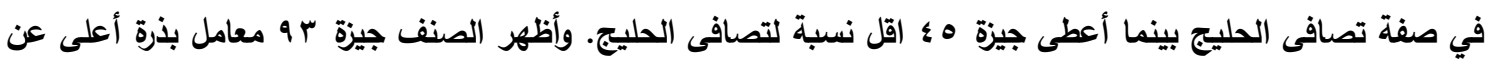

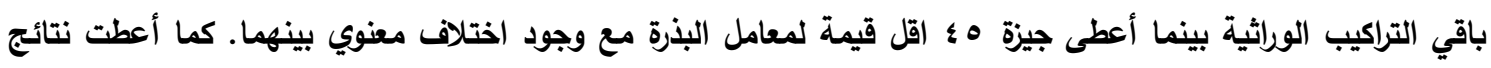

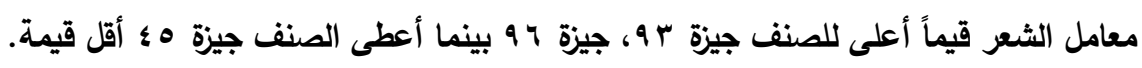
إختلف سلوك الأصناف بإخلاف المواسم ، المواقع وتفاعلاتها سواء من الرتبة الأولى أو من الرتبة الثانية للصفات تحت جله

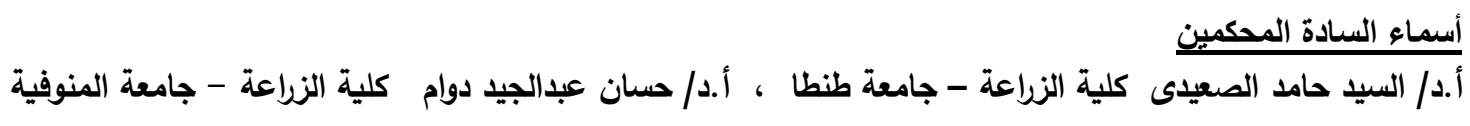


